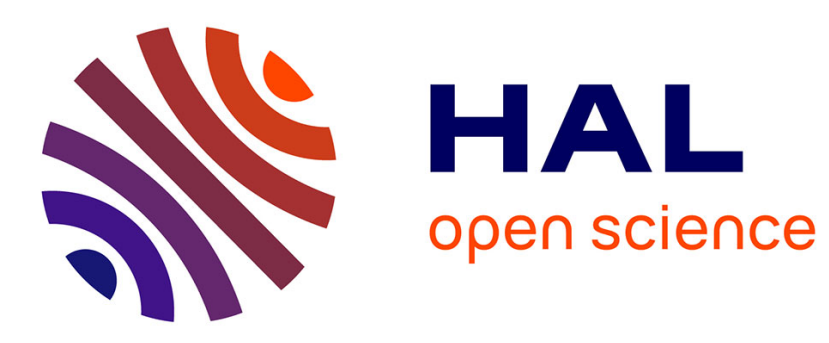

\title{
Brief Overview of Collaborative Approaches in Sustainable Manufacturing
}

Luis M Camarinha-Matos, Andre Dionisio Rocha, Paula Graça

\section{To cite this version:}

Luis M Camarinha-Matos, Andre Dionisio Rocha, Paula Graça. Brief Overview of Collaborative Approaches in Sustainable Manufacturing. 22nd Working Conference on Virtual Enterprises (PROVE), Nov 2021, Saint-Etienne, France. pp.3-18, 10.1007/978-3-030-85969-5_1 . emse-03324330

\section{HAL Id: emse-03324330 \\ https://hal-emse.ccsd.cnrs.fr/emse-03324330}

Submitted on 24 Nov 2021

HAL is a multi-disciplinary open access archive for the deposit and dissemination of scientific research documents, whether they are published or not. The documents may come from teaching and research institutions in France or abroad, or from public or private research centers.
L'archive ouverte pluridisciplinaire HAL, est destinée au dépôt et à la diffusion de documents scientifiques de niveau recherche, publiés ou non, émanant des établissements d'enseignement et de recherche français ou étrangers, des laboratoires publics ou privés. 


\title{
Brief Overview of Collaborative Approaches in Sustainable Manufacturing
}

\author{
Luis M. Camarinha-Matos a ${ }^{\mathrm{a}}$, Andre Dionisio Rocha ${ }^{\mathrm{a}}$ and Paula Graça ${ }^{\mathrm{a}, \mathrm{b}}$ \\ a School of Science and Technology and Uninova-CTS, \\ NOVA University of Lisbon, Campus de Caparica, 2829-516 Caparica, Portugal \\ ${ }^{b}$ Instituto Superior de Engenharia de Lisboa, Instituto Politécnico de Lisboa, \\ Rua Conselheiro Emídio Navarro 1, 1959-007 Lisbon, Portugal \\ cam@uninova.pt, andre.rocha@uninova.pt, paula.graca@isel.pt
}

\begin{abstract}
The manufacturing sector is experiencing a profound transformation as reflected in the Industry 4.0 movement, combined with the growing societal concerns for sustainability. This trend has led to the notion of sustainable manufacturing. On the other hand, the increasing interconnectivity among organisations, people, and physical systems, supported by recent developments in communication technologies, points to the important role that collaborative networks have in the ongoing digital transformation processes. As such, this paper analyses the synergies between sustainable manufacturing and collaborative networks. More specifically, the goal is to analyse how the responsibility for the various facets of sustainability can be distributed among the multiple entities involved in manufacturing. This study is based on both literature survey and our experience in various research projects in the area and is organised according to the typical six dimensions of Industry 4.0. The work is complemented with a brief summary of proposed indicators to measure sustainability under this networked manufacturing perspective.
\end{abstract}

Keywords: Collaborative networks, Sustainability, Sustainable manufacturing, Industry 4.0, Digital transformation, Sustainability indicators.

\section{Introduction}

The manufacturing sector has experienced considerable evolution in the last decade as reflected in the Industry 4.0 and digital transformation "movement". The convergence of multiple new technologies and the political support to this "industrial revolution" led to the emergence of new organisational and managerial forms, new processes, extended notion of product-service, and new business models.

In parallel, the manufacturing world also faces the challenge of coping with a growing societal claim for sustainability. This is reflected, for instance, in the UN Agenda 2030 [1], which establishes 17 goals for sustainable development. Manufacturing has a crucial role in this context, as addressed in the various sub-items of Goal 9, "Build resilient infrastructure, promote inclusive and sustainable industrialisation and foster innovation". But other (indirect) links to manufacturing 
can also be found in other goals of the Agenda, e.g., "double the global rate of improvement in energy efficiency", "achieve higher levels of economic productivity through diversification, technological upgrading and innovation", "promote development-oriented policies that support productive activities, decent job creation, entrepreneurship, creativity and innovation, and encourage the formalisation and growth of micro-, small- and medium-sized enterprises", etc. As such, in recent years the term "sustainable manufacturing" [2] is becoming more relevant.

As identified in [3], there is a great potential for mutual beneficial synergies between the fields of collaborative networks and sustainability science. This was one of the earliest works arguing that sustainability requires a wide collaboration among multiple stakeholders, not being possible to achieve by individual entities. On the other hand, collaborative networks have also been pointed out as a core enabler for Industry 4.0 and digital transformation $[4,5]$. Given this context, this work is guided by the following general research question: What is the role of collaborative networks in sustainable manufacturing? More specifically, we are interested in analysing how the responsibility for the various facets of sustainability can be distributed among the multiple entities involved in networked manufacturing systems.

As this research is ongoing work, this paper mainly tries to identify and categorise relevant examples and trends to help understand the synergies among these three areas: collaborative networks, manufacturing, and sustainability.

\section{Base Concepts and Research Method}

In this section, some base concepts are briefly revisited in order to provide a context for the following discussion.

The notion of sustainability is typically analysed under three perspectives: environmental, economic, and social [3]. Such a notion involves considerable complexity, not only because of this multi-dimensional nature, but also because it calls for a difficult balance among objectives that are often conflicting and involving multiple stakeholders. When it comes to manufacturing, various related terms are often used, including sustainable manufacturing, industrial symbiosis, and circular economy.

Sustainable manufacturing has emerged in recent years as the "integration of processes and systems capable to produce high quality products and services using less and more sustainable resources (energy and materials), being safer for employees, customers and communities surrounding, and being able to mitigate environmental and social impacts throughout its whole life cycle" [6]. A similar definition is provided in [i], which further refers the need to be "economically sound".

Industrial symbiosis can be seen as one specific implementation of sustainable manufacturing representing a "process by which the wastes or by-products of an industry or industrial process become the raw materials for another" [7]. This notion implies a collective endeavour through which a group of separate industries form a kind of collaborative business ecosystem to exchange materials, energy, water and byproducts [8]. It implies moving from a linear model of "take-make-dispose" to a circular model in which waste is valorised as a resource. 
Circular economy is a more general concept, which focuses on "higher resource utilisation by recollecting and reusing components of products after their use is over" [9]. In other words, it "enables the reintegration of materials into production processes through their reuse, recycling, and recovery" [10]. From a traditional point of view, while circular economy focuses on the entire economy, sustainable manufacturing appears focused solely on the manufacturing phase [11]. However, when we take the Industry 4.0 view, and the notion of extended smart product and the need of considering the whole life cycle of the product, the notions of sustainable manufacturing and circular economy get a bigger overlapping.

The effective materialisation of all the above notions implies some form of collaboration among multiple stakeholders, and thus, the role of collaborative networks in support of sustainable manufacturing deserves attention. In fact, the common notion of collaborative network as "composed of a variety of entities organisations people and even smart machines - which are largely autonomous, geographically distributed, and heterogeneous in terms of their operating environment, culture, social capital and goals... that collaborate to (better) achieve common or compatible goals" [12] provides a comprehensive view of the interactions and inter-dependencies among the multiple entities involved in a manufacturing system. The notion of community or business ecosystem, as implicit in Virtual organisation Breeding Environments, helps to build a better perception of coresponsibility of all involved actors regarding the sustainability challenges [3].

In this work, as a preliminary stage to understand the synergies among sustainability, manufacturing, and collaborative networks, we adopted a mixed method, combining a systematic mapping study based on literature with case studies / acquired experiences from various research projects. On the other hand, the study of such synergies is also expected to contribute to a better understanding of the next generation of collaborative networks. In fact, a business ecosystem or any other form of a collaborative network not only involves collaboration but rather a complex and dynamic mix of collaboration and competition. In such business communities, there is some form of "survival instinct" and shared vision that can lead members to align their commitments and to find mutually supportive roles. By further expanding these ideas, we hope to acquire new insights on better organisational and governance principles that will likely contribute to more sustainable business ecosystems.

\section{A Collaborative Networks View of Manufacturing Systems}

Various recent works have presented collaborative networks as one of the core enablers for Industry 4.0 and the ongoing digital transformation process $[4,5,13,14]$. In fact, considering the typical dimensions of the current industrial revolution, including both the manufacturing system and product/service perspectives, it becomes clear that we need to deal with, at all levels, networks involving multiple actors, being them organisations, people, smart machines, and smart systems, with varying degrees of autonomy and heterogeneity. The highlights of such a trend are illustrated in Fig. 1, which go far beyond the traditional view of networks applied to value chains and 
rather influence all dimensions of Industry 4.0.

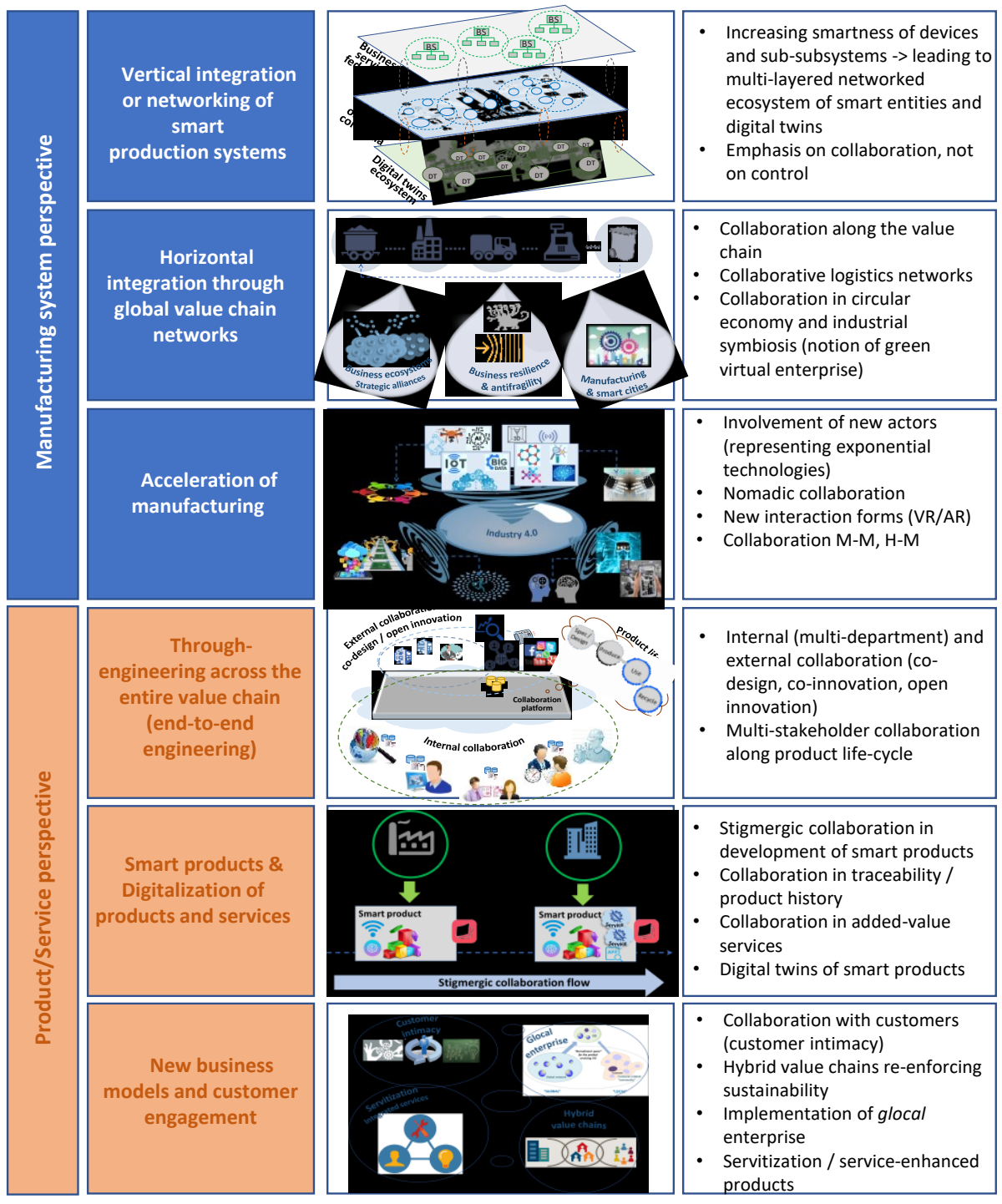

Fig. 1 - Dimensions of Industry 4.0 and role of Collaborative Networks

This view of a manufacturing system as composed of multiple networks of autonomous or partially autonomous entities implies a distribution of responsibilities among these entities. As such, also the issue of sustainability needs to be analysed under a collaborative networks perspective in the sense that multiple entities/subsystems are co-responsible for the sustainability level of the manufacturing system.

The role of CNs in sustainability has been addressed in relation to the horizontal integration dimension, namely in terms of circular economy and industrial symbiosis, or in relation to new business models, such as some cases of hybrid value chains $[10$, 
8]. However, the issue has been less studied in the case of the other dimensions, which justifies an effort to analyse existing trends and relevant examples in order to characterise research gaps.

\section{Trends and Examples}

The latest developments associated with Industry 4.0 have focused on developing solutions aimed at introducing more sustainable manufacturing practices, not only from the point of view of costs and profit but also considering the other two pillars of sustainability, related to social and environmental aspects. Although this trend towards more sustainable ecosystems can be noticed, an assessment is not usually made of how the collaboration aspects are directly or indirectly related to improving these complex ecosystems. These distributed and complex systems imply constant communication between the players to optimise the systems, whether from an economic, social and/or environmental points of view.

The association of the collaborative perspective with these systems is usually not much explicit in the manufacturing literature, besides the obvious case of the horizontal dimension. However, in many studies, it is possible to identify that collaboration is an essential aspect in the design and operation of these complex environments. For example, it is possible to find shopfloors' implementation where machines collaborate with each other and/or with the operators. Another case widely observed in the literature is the optimisation of distributed manufacturing systems where different factories, suppliers, and transportation systems work together to optimise themselves as a whole. Products are also beginning to emerge with new features such as connectivity to the cloud that allows data extraction from products and changing their functionality remotely by manufacturers. This aspect also contributes to the product design being done collaboratively between the company's different departments, including the customer and the product itself in this process. This new reality is becoming clear with the introduction of new emerging technologies such as Additive Manufacturing, Artificial Intelligence or CyberPhysical Systems that will force companies to apply new business models.

A summary of studies focusing on developing sustainable manufacturing systems in which collaborative aspects are presented is shown in Table 1. This table covers the infrastructure perspective and presents examples aiming to increase the sustainability of manufacturing systems through collaboration.

Similar to Table 1, Table 2 presents the elements of collaboration and added value regarding sustainability that are found in studies related to the dimensions of End-toEnd Engineering, Smart Products, and the creation of new business models. 
Table 1 - Examples of sustainability aspects in the manufacturing infrastructure dimensions.

\begin{tabular}{|c|c|c|c|}
\hline & Economic & Social & Environmental \\
\hline 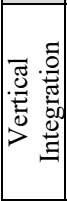 & $\begin{array}{l}\text { - Collaboration between machines to } \\
\text { reduce costs and increase } \\
\text { productivity. }[15,16] \text {. } \\
\text { - Increase productivity using human- } \\
\text { robot collaboration [17, 18]. } \\
\text { - Share factories to increase } \\
\text { efficiency [19]. }\end{array}$ & $\begin{array}{l}\text { - Human-robot collaboration } \\
\text { (Improve working } \\
\text { conditions, reduce health } \\
\text { problems) }[17,18,20,21 \text {, } \\
22] .\end{array}$ & $\begin{array}{l}- \text { Implementation of shared } \\
\text { factories to reduce energy and } \\
\text { natural resources consumption } \\
{[19] \text {. }} \\
\text { - Human robot collaboration in } \\
\text { order to improve recycling } \\
\text { process, reducing waste [21, 22]. }\end{array}$ \\
\hline & $\begin{array}{l}\text { - Collaborative resource allocation. } \\
{[16,23] \text {. }} \\
\text { - Increase efficiency sharing spaces } \\
\text { and machines [24]. } \\
\text { - Shared logistics for cost reduction } \\
\text { [25]. } \\
\text { - Collaborative strategies for pickup } \\
\text { and delivery network of eco- } \\
\text { packages through resource sharing } \\
\text { [26]. } \\
\text { - Contributions of environmental } \\
\text { collaboration to firm performance } \\
\text { [27]. }\end{array}$ & $\begin{array}{l}\text { - Auction-based logistics for } \\
\text { social welfare [25]. } \\
\text { - Collaborative platforms to } \\
\text { ensure human rights } \\
\text { protection, patient } \\
\text { confidentially and welfare. } \\
\text { [23]. } \\
\text { - Role of green supply chain } \\
\text { to improve brands and } \\
\text { customer value [28]. } \\
\text { - Sustainable collaborative } \\
\text { governance of supply } \\
\text { chains [29]. }\end{array}$ & $\begin{array}{l}\text { - Reduce resources' waste sharing } \\
\text { spaces and machines [24]. } \\
\text { - Reduce carbon footprint and } \\
\text { energy consumption through } \\
\text { trustable collaborative supply } \\
\text { chain [23, 30, 31]. } \\
\text { - Various methods to select } \\
\text { suppliers for sustainable supply } \\
\text { chains using the } 3 \text { dimensions of } \\
\text { sustainability }[32,33,34] \text {. }\end{array}$ \\
\hline 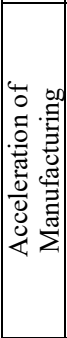 & $\begin{array}{l}\text { - CPS systems for allowing } \\
\text { interoperability among factory } \\
\text { resources [15]. } \\
\bullet \text { Digital Twins to design products by } \\
\text { different teams and in different } \\
\text { stages [35]. } \\
\bullet \text { Digital Twins to optimise shared } \\
\text { resources' allocation [24]. } \\
\text { - Self-organised approaches to } \\
\text { optimise network of resources [19]. } \\
\text { - Blockchain to increase trustability } \\
\text { among suppliers [23]. }\end{array}$ & $\begin{array}{l}\text { - Additive manufacturing } \\
\text { and 3D printing as part of } \\
\text { circular production and } \\
\text { consumption. [36, 37]. } \\
\text { - Digital Twins to increase } \\
\text { the collaboration between } \\
\text { human and robots [17]. } \\
\text { - Blockchain to ensure } \\
\text { social aspects in a } \\
\text { collaborative distributed } \\
\text { ecosystem [23]. }\end{array}$ & $\begin{array}{l}\text { - Distributed manufacturing of 3D } \\
\text { printed products to reduce } \\
\text { energy and material } \\
\text { consumption [38]. } \\
\text { - Overall reduction of energy and } \\
\text { material consumption using } \\
\text { Digital Twins [24, 30]. } \\
\text { - Blockchain technology to allow } \\
\text { a trustable waste and resources } \\
\text { consumption reduction in } \\
\text { collaborative supply chains [23]. }\end{array}$ \\
\hline
\end{tabular}

Table 2 - Examples of sustainability aspects in the product/service dimensions.

\begin{tabular}{|c|c|c|c|}
\hline & Economic & Social & Environmental \\
\hline 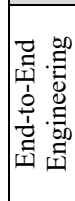 & \begin{tabular}{|l|}
$\bullet$ Co-creation and user \\
innovation $[37,39,40]$. \\
$\bullet$ Shorten design cycles and \\
reduce costs using the data \\
collected from products \\
and customers. [35, 41].
\end{tabular} & $\begin{array}{l}\text {-(Re)design products according to } \\
\text { customer needs and desires } \\
\text { based on product data [39]. } \\
\text { - Guarantee product quality } \\
\text { through remote product analysis } \\
\text { during execution [42]. } \\
\text { - Value co-creation network [40]. }\end{array}$ & $\begin{array}{l}\text { - Utilisation of the collected data } \\
\text { from the product to design more } \\
\text { ecofriendly transport conditions } \\
\text { [43]. }\end{array}$ \\
\hline 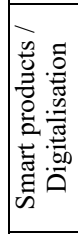 & $\begin{array}{l}\text { - Product data extraction to } \\
\text { (re)design better products } \\
\text { [39]. } \\
\text { - Extract and analyse } \\
\text { products' data along the } \\
\text { supply chain to reduce } \\
\text { costs [39]. } \\
\text { - Symbiosis network [40]. }\end{array}$ & $\begin{array}{l}\text { - Extract data to assess product } \\
\text { quality and execution [42]. } \\
\text { - Extract and analyse data from } \\
\text { the product to reduce delivering } \\
\text { time [39]. }\end{array}$ & $\begin{array}{l}\text { - Constant assessment of products' } \\
\text { conditions during transportation } \\
\text { [43]. } \\
\text { - Extract and analyse products' data } \\
\text { along the supply chain to reduce } \\
\text { environmental impact [39]. } \\
\text { - Smart products contribution to } \\
\text { circular economy [44]. }\end{array}$ \\
\hline 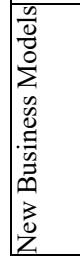 & $\begin{array}{l}\text { - Sharing economy to } \\
\text { increase competitiveness } \\
{[19,24] \text {. }} \\
\text {-Application of industrial } \\
\text { symbiosis }[31,45] \text {. }\end{array}$ & $\begin{array}{l}\bullet \text { Increase customer involvement } \\
{[36,37] \text {. }} \\
\bullet \text { Stigmergic Mass customization, } \\
\text { co-creation, co-design [46]. } \\
\text {-Hybrid value chains and social } \\
\text { innovation }[47,48] \text {. }\end{array}$ & $\begin{array}{l}\bullet \text { Circular economy-based model } \\
{[21,36] \text {. }} \\
\bullet \text { Distributed manufacturing model } \\
{[38,49] \text {. }} \\
\bullet \text { Sharing economy to reduce wastes } \\
\text { and consumptions }[19,24] \text {. } \\
\bullet \text { Application of industrial symbiosis } \\
\text { [31, 45]. } \\
\bullet \text { Global business sustainability [50]. }\end{array}$ \\
\hline
\end{tabular}


It is possible to verify by the results summarised in Table 1 and Table 2 that some work has already been done in order to develop more sustainable systems using as a base the combination of practices of Industry 4.0 and collaborative networks. In most of the studied works, the collaboration aspects are not usually highlighted; nevertheless, the synergy between sustainable manufacturing and collaborative networks can be inferred. For instance, a research project in sustainable manufacturing in which our research centre participated is illustrated in Fig.2, where it is possible to identify the role of collaborative aspects at different levels.

From the analysed examples, as summarised in the tables above, it is possible to verify that the collaborative aspects are already present in various cases of applying the Industry 4.0 concepts to achieve sustainability. It can also be noticed that these aspects appear more frequently in terms of the vertical and horizontal integration dimensions. Another interesting point is that emerging technologies, included under the acceleration of manufacturing, are particularly relevant in the efficient application of the collaborative aspects. However, it is important to underline that the combination of manufacturing, sustainability and collaborative networks are not always explicitly presented in the studied literature, but it is possible to infer their importance, as summarised in Table 1 and Table 2.

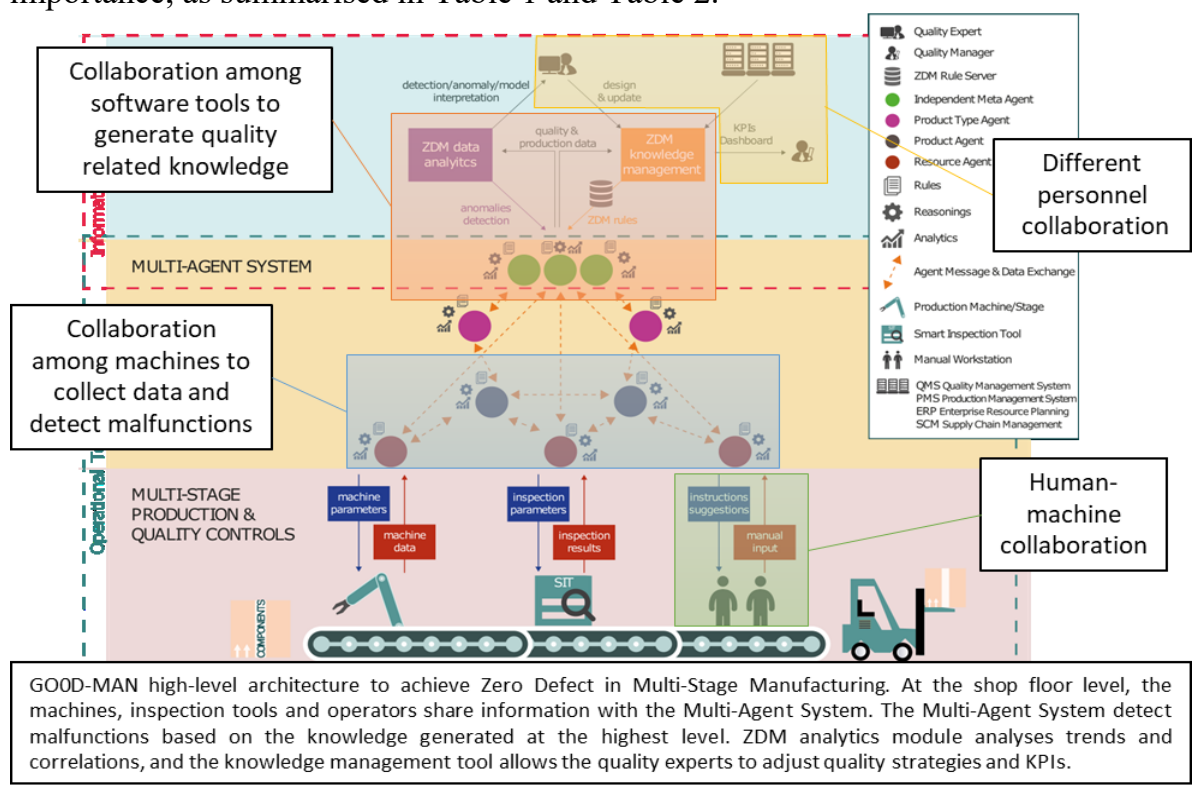

Fig. 2 - GO0DMAN High-Level Architecture and Collaborative Aspects (adapted from [51])

\section{Measuring Sustainability}

Although it is widely agreed that sustainability is one of the main concerns for manufacturing, to be more effective, sustainability must be measured and proper sustainability-related performance indicators established. As summarised in Table 3 
and Table 4, some examples of efforts on measuring sustainability under a collaborative perspective and addressing the economic, social, and environmental concerns can already be found in the literature.

The examples in Table 3, addressing the manufacturing infrastructure perspective, propose mainly metrics and indicators to evaluate sustainability performance, borrowed from traditional manufacturing and supply chains. Concerning the collaboration perspective, some attempts can be found, underlining the importance of collaboration between the various players towards better sustainability.

Table 3 - Examples of sustainability metrics/indicators in the manufacturing infrastructure dimensions.

\begin{tabular}{|c|c|c|c|}
\hline & Economic & Social & Environmental \\
\hline & $\begin{array}{l}\text { - Metrics for evaluation of } \\
\text { manufacturing sustainability } \\
\text { performance at the } \\
\text { production line level [52]. } \\
\text { - Framework to map and } \\
\text { analyse the interconnections } \\
\text { between technical and } \\
\text { economic performance } \\
\text { metrics at the operation [53]. }\end{array}$ & $\begin{array}{l}\text { - Metrics for evaluation of } \\
\text { manufacturing sustainability } \\
\text { performance at the production } \\
\text { line/plant level [52]. } \\
\text { - Framework to map and analyse } \\
\text { the interconnections between } \\
\text { technical and social } \\
\text { performance metrics at the } \\
\text { operation [53]. }\end{array}$ & $\begin{array}{l}\text { - Metrics for evaluation of } \\
\text { manufacturing sustainability } \\
\text { performance at the production } \\
\text { line/plant level [52]. } \\
\text { - Framework to map and analyse the } \\
\text { interconnections between technical } \\
\text { and environmental performance } \\
\text { metrics at the operation [53]. }\end{array}$ \\
\hline & $\begin{array}{l}\text { - Dashboard of KPIs of a } \\
\text { Virtual Factory processes } \\
\text { [54]. } \\
\text { - Framework to develop } \\
\text { metrics for evaluating } \\
\text { system effectiveness to } \\
\text { improve sustainability [55]. } \\
\text { - Proposal for a sustainability } \\
\text { index to show performance } \\
\text { at manufacturer and supply } \\
\text { chain level [56]. } \\
\text { - Measurement of } \\
\text { sustainability performance } \\
\text { in products and processes } \\
\text { for manufacturing } \\
\text { companies [57]. }\end{array}$ & $\begin{array}{l}\text { - Framework to develop metrics } \\
\text { for evaluating system } \\
\text { effectiveness to improve } \\
\text { sustainability [55]. } \\
\text { - Proposal for a sustainability } \\
\text { index to show performance at } \\
\text { manufacturer and supply chain } \\
\text { level [56]. } \\
\text { - Social responsibility metrics to } \\
\text { evaluate and select sustainable } \\
\text { suppliers [32]. } \\
\text { - Measurement of sustainability } \\
\text { performance in products and } \\
\text { processes for manufacturing } \\
\text { companies [57]. } \\
\text { - Sustainability performance } \\
\text { indicators for an Industry } 4.0 \\
\text { virtual learning environment } \\
\text { [58]. }\end{array}$ & $\begin{array}{l}\text { - Dashboard of KPIs of a Virtual } \\
\text { Factory processes [54]. } \\
\text { - Framework to develop metrics for } \\
\text { evaluating system effectiveness to } \\
\text { improve sustainability [55]. } \\
\text { - Proposal for a sustainability index to } \\
\text { show performance at manufacturer } \\
\text { and supply chain level [56]. } \\
\text { - Environmental metrics to evaluate \& } \\
\text { select sustainable suppliers [32]. } \\
\text { - Measurement of sustainability } \\
\text { performance in products and } \\
\text { processes for manufacturing } \\
\text { companies [57]. } \\
\text { - Sustainability performance } \\
\text { indicators for an Industry 4.0 virtual } \\
\text { learning environment [58]. } \\
\text { - Model for the assessment of the } \\
\text { performance of a supply chain, } \\
\text { based the perspectives used in the } \\
\text { balanced scorecard e[59] }\end{array}$ \\
\hline 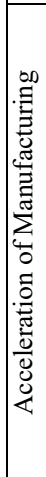 & $\begin{array}{l}\text { - Indicators/practices to } \\
\text { optimise economic returns } \\
\text { [60]. } \\
\text { - Metrics to evaluate the } \\
\text { influence of Industry } 4.0 \text { on } \\
\text { sustainable manufacturing } \\
\text { [11]. } \\
\text { - Study to integrate the } \\
\text { sustainable smart } \\
\text { manufacturing performance } \\
\text { by incorporating sustainable } \\
\text { manufacturing measures } \\
\text { - Metrics framework for } \\
\text { assessing sustainability } \\
\text { benefits in cyber } \\
\text { manufacturing systems [62]. }\end{array}$ & $\begin{array}{l}\text { - Indicators/practices to optimise } \\
\text { social returns [60]. } \\
\text { - Measures for talent } \\
\text { attractiveness in SMEs to } \\
\text { achieve social sustainability in } \\
\text { the cities of the future [63]. } \\
\text { - Metrics to evaluate the } \\
\text { influence of Industry } 4.0 \text { on } \\
\text { sustainable manufacturing [11]. } \\
\text { - Study to integrate the } \\
\text { sustainable smart } \\
\text { manufacturing performance by } \\
\text { incorporating sustainable } \\
\text { manufacturing measures [61]. } \\
\text { - Metrics framework for } \\
\text { assessing sustainability } \\
\text { benefits in cyber } \\
\text { manufacturing systems [62]. }\end{array}$ & $\begin{array}{l}\text { - Indicators/practices to optimise } \\
\text { environmental returns [60]. } \\
\text { - Metrics to evaluate the influence of } \\
\text { Industry } 4.0 \text { on sustainable } \\
\text { manufacturing [11]. } \\
\text { - Study to integrate the sustainable } \\
\text { smart manufacturing performance by } \\
\text { incorporating sustainable } \\
\text { manufacturing measures [61]. } \\
\text { - Metrics framework for assessing } \\
\text { sustainability benefits in cyber } \\
\text { manufacturing systems [62]. }\end{array}$ \\
\hline
\end{tabular}

Table 4 presents examples related to sustainability metrics and indicators focused on smart products, digitalisation and new business models. Under this perspective, the identified attempts are preliminary approaches to measurement models, identification 
of benefits, and insights on the influence of these products and services on sustainable performance. At this level, the collaboration that is more worth highlighting is between human-machine.

Table 4 - Examples of sustainability metrics/indicators in the product/service dimensions.

\begin{tabular}{|c|c|c|c|}
\hline & Economic & Social & Environmental \\
\hline 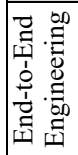 & $\begin{array}{l}\bullet \text { Preliminary approach towards a } \\
\text { measurement model for value } \\
\text { co-creation in service design } \\
\text { [64]. }\end{array}$ & $\begin{array}{l}\text { - Identification of benefits for } \\
\text { customers from co-creation } \\
\text { [65]. }\end{array}$ & \\
\hline 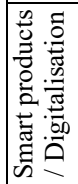 & $\begin{array}{l}\text { - Smart targets to smart energy } \\
\text { systems transition with } \\
\text { economic impact [66]. }\end{array}$ & $\begin{array}{l}\text { - Smart targets to smart energy } \\
\text { systems transition with social } \\
\text { impact [66]. }\end{array}$ & $\begin{array}{l}\text { - Smart targets to smart energy } \\
\text { systems transition with } \\
\text { environmental impact [66]. }\end{array}$ \\
\hline 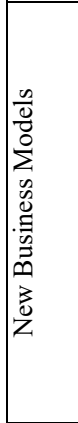 & $\begin{array}{l}\text { - Insights that servitisation and } \\
\text { lean bundles have } \\
\text { complementarity effects on } \\
\text { sustainable performance [67]. } \\
\text { - Index to assess the } \\
\text { sustainability and the } \\
\text { circularity of manufacturing } \\
\text { companies [10]. } \\
\text { - Framework based on concepts } \\
\text { of circular economy to assess } \\
\text { sustainability performance of } \\
\text { manufacturing companies [60]. } \\
\text { - Quantitative framework for } \\
\text { Industry 4.0 enabled circular } \\
\text { economy [68]. } \\
\end{array}$ & $\begin{array}{l}\text { - Index to assess the } \\
\text { sustainability and the } \\
\text { circularity of manufacturing } \\
\text { companies [10]. } \\
\text { Framework based on concepts } \\
\text { of circular economy to assess } \\
\text { sustainability performance of } \\
\text { manufacturing companies } \\
\text { [60]. }\end{array}$ & $\begin{array}{l}\text {-Insights that servitisation and } \\
\text { lean bundles have } \\
\text { complementarity effects on } \\
\text { sustainable performance [67]. } \\
\text { - Index to assess the sustainability } \\
\text { and the circularity of } \\
\text { manufacturing companies [10]. } \\
\text { - Framework based on concepts } \\
\text { of circular economy to assess } \\
\text { the sustainability performance of } \\
\text { manufacturing companies [60]. } \\
\text { - Quantitative framework for } \\
\text { Industry } 4.0 \text { enabled circular } \\
\text { economy [68]. }\end{array}$ \\
\hline
\end{tabular}

This study only presents some examples and not an exhaustive list of cases. Nevertheless, and despite some valuable attempts, there is still a lack of concrete performance indicators to assess the benefits of collaboration towards a better manufacturing sustainability performance.

\section{Conclusions}

Sustainability is a major challenge for modern manufacturing systems. Although the manufacturing sector has received a renewed attention in the last years, as reflected in the multiplication of initiatives around Industry 4.0 and digital transformation, making such systems more sustainable remains a crucial challenge.

On the other hand, as manufacturing systems become increasingly smart, autonomous, and interconnected, reflecting a kind of distributed intelligence, the issues of sustainability need to be analysed under a distributed and collaborative perspective. To this aim, the synergies between collaborative networks and sustainable manufacturing need to be further explored.

This study reveals a good number of steps in this direction, both at the manufacturing infrastructure level and at the product/service/business model level. 
However, the collaboration aspects among all the entities present in these ecosystems are still not usually considered and analysed. But it is clear that despite the identified positive examples, there is a need to substantially pursue the exploitation of synergies among the areas of sustainability, manufacturing, and collaborative networks and develop corresponding assessment methodologies and indicators.

Acknowledgments. This work was funded in part by Fundação para a Ciência e Tecnologia through the program UIDB/00066/2020 and Center of Technology and Systems (CTS).

\section{References}

[1] United Nations. Transforming our world: the 2030 agenda for sustainable development department of economic and social affairs. https://sdgs.un.org/2030agenda, 2015. URL https://sdgs.un.org/2030agenda. (accessed 6 Apr 2021).

[2] OCDE. The OECD sustainable manufacturing toolkit. https://www.oecd.org/innovation/green/toolkit/48704993.pdf, 2021. URL https://www.oecd.org/innovation/green/toolkit/48704993.pdf. (accessed 6 Apr 2021).

[3] L. M. Camarinha-Matos, H. Afsarmanesh, and X. Boucher. The role of collaborative networks in sustainability. In: Collaborative Networks for a Sustainable World, pages 116, Berlin, Heidelberg, 2010. Springer Berlin Heidelberg. doi: https://doi.org/10.1007/978-3-642-15961-9_1.

[4] L. M. Camarinha-Matos, R. Fornasiero, and H. Afsarmanesh. Collaborative networks as a core enabler of industry 4.0. In: Collaboration in a Data-Rich World, pages 3-17, Cham, 2017. Springer International Publishing.

[5] L. M. Camarinha-Matos, R. Fornasiero, J. Ramezani, and F. Ferrada. Collaborative networks: A pillar of digital transformation. Applied Sciences, 9 (24), 2019. doi: https://doi.org/10.3390/app9245431.

[6] C. Gonçalves Machado, M. P. Winroth, and E. Hans Dener Ribeiro da Silva. Sustainable manufacturing in industry 4.0: an emerging research agenda. International Journal of Production Research, 58 (5): 1462-1484, Mar 2020. doi: 10.1080/00207543.2019.1652777.

[7] EGC. https://ec.europa.eu/environment/europeangreencapital/wpcontent/uploads/2018/05/Industrial_Symbiosis.pdf, 2018. URL https://ec.europa.eu/environment/europeangreencapital/wp-content/uploads/2018/05/Industrial_Symbiosis.pdf. (accessed 2 Apr 2021).

[8] B. Baldassarre, M. Schepers, N. Bocken, E. Cuppen, G. Korevaar, and G. Calabretta. Industrial symbiosis: towards a design process for eco-industrial clusters by integrating circular economy and industrial ecology perspectives. Journal of Cleaner Production, 216: 446-460, 2019. doi: https://doi.org/10.1016/j.jclepro.2019.01.091.

[9] F. Pomponi and A. Moncaster. Circular economy for the built environment: A research framework. Journal of Cleaner Production, 143: 710-718, 2017. doi: https://doi.org/10.1016/j.jclepro.2016.12.055.

[10] Susana Garrido Azevedo, Radu Godina, and João Carlos de Oliveira Matias. Proposal of a sustainable circular index for manufacturing companies. Resources, 6 (4), 2017. doi: 10.3390/resources6040063.

[11] Christian Enyoghasi and Fazleena Badurdeen. Industry 4.0 for sustainable manufacturing: Opportunities at the product, process, and system levels. Resources, Conservation and Recycling, 166: 105362, 2021. doi: https://doi.org/10.1016/j.resconrec.2020.105362. 
[12] Luis M. Camarinha-Matos, Hamideh Afsarmanesh, Nathalie Galeano, and Arturo Molina. Collaborative networked organisations - concepts and practice in manufacturing enterprises. Computers \& Industrial Engineering, 57 (1): 46-60, 2009. doi: https://doi.org/10.1016/j.cie.2008.11.024. Collaborative e-Work Networks in Industrial Engineering.

[13] Leonardo Moraes Aguiar Lima Dos Santos, Matheus Becker da Costa, João Victor Kothe, Guilherme Brittes Benitez, Jones Luís Schaefer, Ismael Cristofer Baierle, and Elpidio Oscar Benitez Nara. Industry 4.0 collaborative networks for industrial performance. Journal of Manufacturing Technology Management, 32 (2): 245-265, Jan 2021. doi: 10.1108/JMTM-04-2020-0156.

[14] I. A. R. Torn and T. H. J. Vaneker. Mass personalisation with industry 4.0 by smes: a concept for collaborative networks. Procedia Manufacturing, 28: 135-141, Jan 2019. doi: https://doi.org/10.1016/j.promfg.2018.12.022.

[15] Göran Adamson, Lihui Wang, and Philip Moore. Feature-based control and information framework for adaptive and distributed manufacturing in cyber physical systems. Journal of Manufacturing Systems, 43: 305-315, Apr 2017. doi: https://doi.org/10.1016/j.jmsy.2016.12.003.

[16] Kai Li, Tao Zhou, Bo hai Liu, and Hui Li. A multi-agent system for sharing distributed manufacturing resources. Expert Systems with Applications, 99: 32-43, 2018. doi: https://doi.org/10.1016/j.eswa.2018.01.027.

[17] Qibing Lv, Rong Zhang, Xuemin Sun, Yuqian Lu, and Jinsong Bao. A digital twin-driven human-robot collaborative assembly approach in the wake of covid-19. Journal of Manufacturing Systems, Feb 2021. doi: https://doi.org/10.1016/j.jmsy.2021.02.011.

[18] Luca Gualtieri, Ilaria Palomba, Fabio A. Merati, Erwin Rauch, and Renato Vidoni. Design of human-centered collaborative assembly workstations for the improvement of operators' physical ergonomics and production efficiency: A case study, 2020.

[19] Pulin Li and Pingyu Jiang. Enhanced agents in shared factory: Enabling high-efficiency self-organisation and sustainability of the shared manufacturing resources. Journal of Cleaner Production, 292: 126020, Apr 2021. doi: https://doi.org/10.1016/j.jclepro.2021.126020.

[20] Fazel Ansari, Philipp Hold, and Marjan Khobreh. A knowledge-based approach for representing jobholder profile toward optimal human-machine collaboration in cyber physical production systems. CIRP Journal of Manufacturing Science and Technology, 28: 87-106, Jan 2020. doi: https://doi.org/10.1016/j.cirpj.2019.11.005.

[21] Arantxa Renteria and Esther Alvarez-de-los Mozos. Human-robot collaboration as a new paradigm in circular economy for weee management. Procedia Manufacturing, 38: 375382, Jan 2019. doi: https://doi.org/10.1016/j.promfg.2020.01.048.

[22] Hendrik Poschmann, Holger Brüggemann, and Daniel Goldmann. Fostering end-of-life utilization by information-driven robotic disassembly. Procedia CIRP, 98: 282-287, Jan 2021. doi: https://doi.org/10.1016/j.procir.2021.01.104.

[23] Arvind Upadhyay, Sumona Mukhuty, Vikas Kumar, and Yigit Kazancoglu. Blockchain technology and the circular economy: Implications for sustainability and social responsibility. Journal of Cleaner Production, 293: 126130, Apr 2021.

[24] Gang Wang, Geng Zhang, Xin Guo, and Yingfeng Zhang. Digital twin-driven service model and optimal allocation of manufacturing resources in shared manufacturing. Journal of Manufacturing Systems, 59: 165-179, Apr 2021. doi: https://doi.org/10.1016/j.jmsy.2021.02.008.

[25] Kai Kang, Ray Y. Zhong, Su Xiu Xu, Bing Qing Tan, Lihui Wang, and Tao Peng. Auction-based cloud service allocation and sharing for logistics product service system. Journal of Cleaner Production, 278: 123881, 2021. doi: https://doi.org/10.1016/j.jclepro.2020.123881. 
[26] Yong Wang, Shouguo Peng, Xiangyang Guan, Jianxin Fan, Zheng Wang, Yong Liu, and Haizhong Wang. Collaborative logistics pickup and delivery problem with eco-packages based on time-space network. Expert Systems with Applications, 170: 114561, May 2021. doi: https://doi.org/10.1016/j.eswa.2021.114561.

[27] K. Grekova, R. J. Calantone, H. J. Bremmers, J. H. Trienekens, and S. W. F. Omta. How environmental collaboration with suppliers and customers influences firm performance: evidence from dutch food and beverage processors. Journal of Cleaner Production, 112: 1861-1871, Jan 2016. doi: https://doi.org/10.1016/j.jclepro.2015.03.022.

[28] Katrina Lintukangas, Anni-Kaisa Kähkönen, and Paavo Ritala. Supply risks as drivers of green supply management adoption. Journal of Cleaner Production, 112: 1901-1909, Jan 2016. doi: https://doi.org/10.1016/j.jclepro.2014.10.089.

[29] Jiguang Wang and Bing Ran. Sustainable collaborative governance in supply chain. Sustainability, 10 (1), 2018. doi: 10.3390/su10010171.

[30] Moritz Glatt, Patrick Kölsch, Carina Siedler, Pascal Langlotz, Svenja Ehmsen, and Jan C. Aurich. Edge-based digital twin to trace and ensure sustainability in cross-company production networks. Procedia CIRP, 98: 276-281, Jan 2021. doi: https://doi.org/10.1016/j.procir.2021.01.103.

[31] Pi-Cheng Chen and Kun-Hsing Liu. Development of an interactive industrial symbiosis query system with structured industrial waste database in taiwan. Journal of Cleaner Production, 297: 126673, May 2021. doi: https://doi.org/10.1016/j.jclepro.2021.126673.

[32] Joseph Sarkis and Dileep G. Dhavale. Supplier selection for sustainable operations: A triple-bottom-line approach using a bayesian framework. International Journal of Production Economics, 166: 177-191, Aug 2015. doi: https://doi.org/10.1016/j.ijpe.2014.11.007.

[33] Andrew C. Trapp and Joseph Sarkis. Identifying robust portfolios of suppliers: a sustainability selection and development perspective. Journal of Cleaner Production, 112: 2088-2100, Jan 2016. doi: https://doi.org/10.1016/j.jclepro.2014.09.062.

[34] Chong Wu and David Barnes. An integrated model for green partner selection and supply chain construction. Journal of Cleaner Production, 112: 2114-2132, Jan 2016. doi: https://doi.org/10.1016/j.jclepro.2015.02.023.

[35] Fei Tao, Fangyuan Sui, Ang Liu, Qinglin Qi, Meng Zhang, Boyang Song, Zirong Guo, Stephen C.-Y. Lu, and A. Y.C. Nee. Digital twin-driven product design framework. International Journal of Production Research, 57 (12): 3935-3953, Jun 2019. doi: 10.1080/00207543.2018.1443229.

[36] Chris Turner, Mariale Moreno, Luigi Mondini, Konstantinos Salonitis, Fiona Charnley, Ashutosh Tiwari, and Windo Hutabarat. Sustainable production in a circular economy: A business model for re-distributed manufacturing. Sustainability, 11 (16), 2019. doi: $10.3390 /$ su11164291.

[37] Thierry Rayna, Ludmila Striukova, and John Darlington. Co-creation and user innovation: The role of online 3d printing platforms. Journal of Engineering and Technology Management, 37: 90-102, Jul $2015 . \quad$ doi: https://doi.org/10.1016/j.jengtecman.2015.07.002.

[38] Felipe Cerdas, Max Juraschek, Sebastian Thiede, and Christoph Herrmann. Life cycle assessment of $3 \mathrm{~d}$ printed products in a distributed manufacturing system. Journal of Industrial Ecology, 21 (S1): S80-S93, Nov 2017. doi: 10.1111/jiec.12618.

[39] Pai Zheng, Tzu-Jui Lin, Chun-Hsien Chen, and Xun Xu. A systematic design approach for service innovation of smart product-service systems. Journal of Cleaner Production, 201: 657-667, Nov 2018. doi: https://doi.org/10.1016/j.jclepro.2018.08.101.

[40] Dao Yin, Xinguo Ming, and Xianyu Zhang. Sustainable and smart product innovation ecosystem: An integrative status review and future perspectives. Journal of Cleaner Production, 274: 123005, 2020. doi: https://doi.org/10.1016/j.jclepro.2020.123005. 
[41] Wim J.C. Verhagen, Bastiaan de Vrught, Joost Schut, and Richard Curran. A method for identification of automation potential through modelling of engineering processes and quantification of information waste. Advanced Engineering Informatics, 29 (3): 307-321, Aug 2015. doi: https://doi.org/10.1016/j.aei.2015.03.003.

[42] Elaheh Maleki, Farouk Belkadi, Nikoletta Boli, Berend Jan van der Zwaag, Kosmas Alexopoulos, Spyridon Koukas, Mihai Marin-Perianu, Alain Bernard, and Dimitris Mourtzis. Ontology-based framework enabling smart product-service systems: Application of sensing systems for machine health monitoring. IEEE Internet of Things Journal, 5 (6): 4496-4505, 2018. doi: 10.1109/JIOT.2018.2831279.

[43] Mará Inés Cabot, Amalia Luque, Ana De Las Heras, and Francisco Aguayo. Aspects of sustainability and design engineering for the production of interconnected smart food packaging. PloS one, $14 \quad$ (5): e0216555, 2019. doi: https://doi.org/10.1371/journal.pone.0216555.

[44] Andres Alcayaga and Erik G Hansen. Smart products as enabler for circular business models: the case of b2b textile washing services. In 3rd PLATE 2019 Conference, Berlin, Germany, pages 18-20, 2019.

[45] N. Gao, Y. Li, Y. Mai, and H. Xu. Optimisation of multiple products transportation under the background of industrial symbiosis network. In 2020 IEEE International Conference on Industrial Engineering and Engineering Management (IEEM), 2020 IEEE International Conference on Industrial Engineering and Engineering Management (IEEM), pages 1281-1285, 2020. doi: 10.1109/IEEM45057.2020.9309810.

[46] Rotimi Ogunsakin, Cesar A. Marin, and Nikolay Mehandjiev. Towards engineering manufacturing systems for mass personalisation: a stigmergic approach. International Journal of Computer Integrated Manufacturing, 34 (4): 341-369, Apr 2021. doi: 10.1080/0951192X.2020.1858508.

[47] Valeria Budinich, Kimberly Manno Reott, and Stephanie Schmidt. Hybrid value chains: Social innovations and the development of the small farmer irrigation market in mexico. Available at SSRN 981223, 2007.

[48] B Doherty and P Kittipanya-Ngam. The role of social enterprise hybrid business models in inclusive value chain development. sustainability 2021, 13, 499, 2021.

[49] H. Gupta, J. N. Lawal, I. J. Orji, and S. Kusi-Sarpong. Closing the gap: The role of distributed manufacturing systems for overcoming the barriers to manufacturing sustainability. IEEE Transactions on Engineering Management, pages 1-20, 2021. doi: 10.1109/TEM.2021.3059231.

[50] Göran Svensson, Carmen Padin, and David Eriksson. Glocal business sustainability performance beyond zero! International Journal of Procurement Management, 9 (1): 1526, Jan 2016. doi: 10.1504/IJPM.2016.073385.

[51] G. Angione, C. Cristalli, J. Barbosa, and P. Leitão. Integration challenges for the deployment of a multi-stage zero-defect manufacturing architecture. In 2019 IEEE 17th International Conference on Industrial Informatics (INDIN), volume 1 of 2019 IEEE 17th International Conference on Industrial Informatics (INDIN), pages 1615-1620, 2019. doi: 10.1109/INDIN41052.2019.8972259.

[52] Aihua Huang and Fazleena Badurdeen. Metrics-based approach to evaluate sustainable manufacturing performance at the production line and plant levels. Journal of Cleaner Production, 192: 462-476, Aug 2018. doi: https://doi.org/10.1016/j.jclepro.2018.04.234.

[53] Hao Zhang, Anthony Veltri, Javier Calvo-Amodio, and Karl R. Haapala. Making the business case for sustainable manufacturing in small and medium-sized manufacturing enterprises: A systems decision making approach. Journal of Cleaner Production, 287: 125038, Mar 2021. doi: https://doi.org/10.1016/j.jclepro.2020.125038.

[54] Yuqiuge Hao, Petri Helo, and Ahm Shamsuzzoha. Virtual factory system design and implementation: integrated sustainable manufacturing. International Journal of Systems 
Science: Operations \& Logistics, 5 (2): 116-132, Apr 2018. doi: 10.1080/23302674.2016.1242819.

[55] Yoram Koren, Xi Gu, Fazleena Badurdeen, and I. S. Jawahir. Sustainable living factories for next generation manufacturing. Procedia Manufacturing, 21: 26-36, Jan 2018. doi: https://doi.org/10.1016/j.promfg.2018.02.091.

[56] Miguel F. Salvado, Susana G. Azevedo, JoÃ£o C. O. Matias, and LuÃ-s M. Ferreira. Proposal of a sustainability index for the automotive industry. Sustainability, 7 (2): 21132144, 2015. doi: 10.3390/su7022113.

[57] Shaw C Feng, Che-Bong Joung, and Gang Li. Development overview of sustainable manufacturing metrics. In Proceedings of the 17th CIRP international conference on life cycle engineering, volume 6, page 12. Citeseer, 2010.

[58] Omar Chaim, Bernd Muschard, Edson Cazarini, and Henrique Rozenfeld. Insertion of sustainability performance indicators in an industry 4.0 virtual learning environment. Procedia Manufacturing, 21: 446-453, Jan 2018. doi: https://doi.org/10.1016/j.promfg.2018.02.143.

[59] Luís Miguel D. F. Ferreira, Cristóvão Silva, and Susana Garrido Azevedo. An environmental balanced scorecard for supply chain performance measurement (env_bsc_4_scpm). Benchmarking: An International Journal, 23 (6): 1398-1422, Jan 2016. doi: 10.1108/BIJ-08-2013-0087.

[60] Himanshu Gupta, Ashwani Kumar, and Pratibha Wasan. Industry 4.0, cleaner production and circular economy: An integrative framework for evaluating ethical and sustainable business performance of manufacturing organisations. Journal of Cleaner Production, 295: 126253, May 2021. doi: https://doi.org/10.1016/j.jclepro.2021.126253.

[61] Mohamed Abubakr, Adel T. Abbas, Italo Tomaz, Mahmoud S. Soliman, Monis Luqman, and Hussien Hegab. Sustainable and smart manufacturing: An integrated approach. Sustainability, 12 (6), 2020. doi: 10.3390/su12062280.

[62] Zhengyi Song and Young Moon. Assessing sustainability benefits of cybermanufacturing systems. The International Journal of Advanced Manufacturing Technology, 90 (5-8): 1365-1382, 9 2017. doi: 10.1007/s00170-016-9428-0.

[63] Dominik T. Matt, Guido Orzes, Erwin Rauch, and Patrick Dallasega. Urban production a socially sustainable factory concept to overcome shortcomings of qualified workers in smart smes. Computers \& Industrial Engineering, 139: 105384, Jan 2020. doi: https://doi.org/10.1016/j.cie.2018.08.035.

[64] Antonio Botti, Mara Grimaldi, and Massimiliano Vesci. Customer Value Co-creation in a Service-Dominant Logic Perspective: Some Steps Toward the Development of a Measurement Scale, pages 137-157. Springer International Publishing, Cham, 2018. doi: 10.1007/978-3-319-61967-5_8.

[65] Ae Ri Lee and Kyung Kyu Kim. Customer benefits and value co-creation activities in corporate social networking services. Behaviour \& Information Technology, 37 (7): 675692, 2018. doi: 10.1080/0144929X.2018.1474252.

[66] Ibrahim Dincer and Canan Acar. Smart energy systems for a sustainable future. Applied Energy, 194: 225-235, May 2017. doi: https://doi.org/10.1016/j.apenergy.2016.12.058.

[67] Zirong Hao, Chenguang Liu, and Mark Goh. Determining the effects of lean production and servitisation of manufacturing on sustainable performance. Sustainable Production and Consumption, 25: 374-389, Jan 2021. doi: https://doi.org/10.1016/j.spc.2020.11.018.

[68] Marco Spaltini, Andrea Poletti, Federica Acerbi, and Marco Taisch. A quantitative framework for industry 4.0 enabled circular economy. Procedia CIRP, 98: 115-120, Jan 2021. doi: https://doi.org/10.1016/j.procir.2021.01.015. 